\title{
Chondrocytes Cocultured with Stromal Vascular Fraction of Adipose Tissue Present More Intense Chondrogenic Characteristics Than with Adipose Stem Cells
}

Citation for published version (APA):

Wu, L., Prins, H-J., Leijten, J., Helder, M. N., Evseenko, D., Moroni, L., van Blitterswijk, C. A., Lin, Y., \& Karperien, M. (2016). Chondrocytes Cocultured with Stromal Vascular Fraction of Adipose Tissue Present More Intense Chondrogenic Characteristics Than with Adipose Stem Cells. Tissue Engineering, 22(3-4), 336-348. https://doi.org/10.1089/ten.tea.2015.0269

Document status and date:

Published: 01/02/2016

DOI:

10.1089/ten.tea.2015.0269

Document Version:

Publisher's PDF, also known as Version of record

Document license:

Taverne

Please check the document version of this publication:

- A submitted manuscript is the version of the article upon submission and before peer-review. There can be important differences between the submitted version and the official published version of record. People interested in the research are advised to contact the author for the final version of the publication, or visit the DOI to the publisher's website.

- The final author version and the galley proof are versions of the publication after peer review.

- The final published version features the final layout of the paper including the volume, issue and page numbers.

Link to publication

\footnotetext{
General rights rights.

- You may freely distribute the URL identifying the publication in the public portal. please follow below link for the End User Agreement:

www.umlib.nl/taverne-license

Take down policy

If you believe that this document breaches copyright please contact us at:

repository@maastrichtuniversity.nl

providing details and we will investigate your claim.
}

Copyright and moral rights for the publications made accessible in the public portal are retained by the authors and/or other copyright owners and it is a condition of accessing publications that users recognise and abide by the legal requirements associated with these

- Users may download and print one copy of any publication from the public portal for the purpose of private study or research.

- You may not further distribute the material or use it for any profit-making activity or commercial gain

If the publication is distributed under the terms of Article 25fa of the Dutch Copyright Act, indicated by the "Taverne" license above,

Download date: 26 Apr. 2023 


\title{
Chondrocytes Cocultured with Stromal Vascular Fraction of Adipose Tissue Present More Intense Chondrogenic Characteristics Than with Adipose Stem Cells
}

\author{
Ling Wu, PhD, ${ }^{1,2}$ Henk-Jan Prins, PhD, ${ }^{3,4}$ Jeroen Leijten, PhD, Marco N. Helder, PhD, Denis Evseenko, PhD, \\ Lorenzo Moroni, PhD, ${ }^{6, *}$ Clemens A. van Blitterswijk, PhD, ${ }^{6, *}$ Yunfeng Lin, DDS, and Marcel Karperien, $\mathrm{PhD}^{1}$
}

Partial replacement of chondrocytes by stem cells has been proposed to improve the performance of autologous chondrocyte implantation (ACI). Our previous studies showed that the increased cartilage production in pellet cocultures of chondrocytes and mesenchymal stem cells (MSCs) is due to a trophic role of the MSCs by stimulating chondrocyte proliferation and matrix production rather than MSCs actively undergoing chondrogenic differentiation. The aim of this study is to compare the trophic effects of stromal vascular fraction cells (SVF) and in vitro expanded adipose stem cells (ASC). SVF and culture-expanded ASC $(n=9)$ were cocultured with primary human chondrocytes in pellets. By glycosaminoglycan (GAG) and DNA assays, we showed that coculture pellets of SVF and chondrocytes have more GAG deposition than that of ASC and chondrocytes. Results of the short tandem repeats analysis indicated that the increase in the chondrocyte proportion in the coculture pellets is more pronounced in the SVF coculture group than in the ASC coculture group. Using flow cytometry and microarray, we demonstrated that SVF and ASC have different characteristics in cell surface markers and gene expression profiles. SVF is more heterogeneous than ASC, whereas ASC is more enriched in cells from the mesenchymal lineage than SVF. By subcutaneous implantation into nude mice, we showed that constructs of SVF and chondrocytes are better in depositing cartilage matrix than the mixture of ASC and chondrocytes. Taken together, SVF is better than ASC in terms of forming cartilage matrix in pellet coculture and in coimplantation models omitting the need for prior cell expansion. Our study suggests that the SVF in combination with primary human chondrocytes may be a good cell combination for one-stage cartilage repair.

\section{Introduction}

A S SELF-REPAIR capacity of cartilage tissue is very limited, full-thickness articular cartilage defects usually lead to the development of osteoarthritis, resulting in serious pain and movement limitations. ${ }^{1}$ Current treatments for cartilage defects in young patients include microfracturing, ${ }^{2}$ mosaicplasty, and autologous chondrocyte implantation (ACI). ${ }^{3}$ However, each of these treatments has limitations.
Fibrocartilage is usually formed after microfracturing, which has inferior mechanical properties compared to native cartilage tissue. ${ }^{4}$ Mosaicplasty often causes donor-site morbidity and postoperative pain. ${ }^{5}$ The drawbacks of ACI are the necessity of two surgical interventions in a time span of several weeks, which is required for the obligatory cell expansion in vitro, dedifferentiation of chondrocytes during this in vitro expansion, and unpredictable long-term outcome. ${ }^{4,6}$

\footnotetext{
${ }^{1}$ Department of Developmental BioEngineering, MIRA-Institute for Biomedical Technology and Technical Medicine, University of Twente, Enschede, The Netherlands.

${ }^{2}$ Department of Orthopedic Surgery, Orthopedic Hospital Research Center, David Geffen School of Medicine, University of California, Los Angeles, California.

${ }^{3}$ Department of Oral Cell Biology, Academic Center for Dentistry, Amsterdam, The Netherlands.

${ }^{4}$ Department of Oral \& Maxillofacial Surgery, VU Medical Center, Amsterdam, The Netherlands.

${ }^{5}$ Department of Orthopedics, VU Medical Center, Amsterdam, The Netherlands.

${ }^{6}$ Department of Tissue Regeneration, MIRA-Institute for Biomedical Technology and Technical Medicine, University of Twente, Enschede, The Netherlands.

${ }^{7}$ State Key Laboratory for Oral Diseases, West China School of Stomatology, Sichuan University, Chengdu, China.

*Current affiliation: Department of Complex Tissue Regeneration (CTR), MERLN Institute for Technology-Inspired Regenerative Medicine, Maastricht University, The Netherlands.
} 
Therefore, clinicians never stopped looking for new therapies that regenerate cartilage defects without the abovementioned issues. With the progress of stem cell biology in recent years, it has been proposed to replace part of the chondrocytes in ACI by other cell sources to avoid the present obligatory, costly, and time-consuming cell expansion phase. Such approach would enable a one-step surgery. Previous studies have mainly focused on bone marrowderived mesenchymal stem cells (BM-MSCs). ${ }^{7-9}$ However, partial replacement of chondrocytes with BM-MSCs is far from optimal because of pain and donor-site morbidity during isolation and the relatively low amount of BM-MSCs in bone marrow aspirates. ${ }^{10}$ Other sources of MSCs are, therefore, becoming more and more attractive.

Adipose tissue-derived stromal cells or adipose stem cells (ASC) are attractive sources for cartilage tissue engineering, because they are abundant in adipose tissue, which is more easily accessible than bone marrow. ${ }^{11}$ These cells can be easily isolated by liposuction with relatively low morbidity and pain. Most importantly, ASC are, like BM-MSCs, able to differentiate into various cell types of the mesodermal lineage, including adipocytes, osteoblasts, chondrocytes, and myocytes under specific culture conditions in vitro. ${ }^{12}$ Isolation of ASC usually involves several steps: tissues are first minced, digested with collagenase, and fractionated by differential centrifugation. The resulting pelleted stromal vascular fraction (SVF) is resuspended and then placed in culture flasks ${ }^{13}$ to isolate the plastic-adherent ASC subpopulation.

Most researchers have focused on the expanded plasticadherent ASC subpopulation, while limited work has been done using the minimally processed SVF cell population. Recent reports have indicated that SVF cells and ASC exhibit different features and properties. ${ }^{14,15}$ From the perspective of clinical practice, SVF cells have great advantages over ASC, since it is possible to harvest them during the operative procedure itself by processing in the operation theatre and putting them back into the patient without laboratory expansion, which is required for the isolation of ASC. Because adipose tissue is an abundant source of stem cells, cell numbers required for reimplantation can easily be obtained.

In our previous report, ${ }^{16}$ pellet coculture of chondrocytes and bone marrow-derived human MSCs (hMSCs) was shown to benefit cartilage matrix formation. In these pellet cocultures, we showed that cartilage matrix genes were mainly expressed by chondrocytes. Furthermore, we showed that the ratio of MSCs decreased dramatically due to massive cell death of MSCs by apoptosis and by stimulation of chondrocyte proliferation in coculture with MSCs. The stimulation of proliferation was at least partly mimicked by culturing chondrocytes in MSC-conditioned medium. These findings were confirmed by an independent study performed by Acharya et $_{\text {al. }}{ }^{17}$

This, and our study, demonstrated a new mechanism of cellular interaction in coculture pellets of MSCs and chondrocytes. Both studies showed that the beneficial effects on cartilage matrix formation in coculture pellets of MSCs and chondrocytes were due to trophic effects of MSCs stimulating chondrocyte proliferation and cartilage matrix deposition rather than MSCs actively undergoing chondrogenic differentiation. Our follow-up study then showed that these trophic effects are independent of culture conditions and was found in cocultures of chondrocytes with MSCs derived from various tissues. ${ }^{18}$ The term trophic effects initially refer to bioactive molecules produced by nerve terminals, which are not neurotransmitters. ${ }^{19}$ In relation to MSCs, the term trophic was first used to describe the process in which MSCs secrete factors that stimulate nearby cells to release functionally bioactive molecules. ${ }^{20}$

Later, the term also relates to the effect of the factors produced by MSC on viability, proliferation, and matrix production of the neighboring cells. This concept has resulted in a paradigm shift in the way MSCs are involved in tissue repair. While traditionally it was believed that MSCs mainly repair damaged tissue by differentiating into specific cell types and replacing lost cells, ${ }^{21}$ nowadays the trophic role of the MSC in tissue repair is considered more important. ${ }^{22}$ Besides, in cartilage regeneration, these effects were also reported in promoting gain of coordinated functions in stroked brain of rats, ${ }^{23}$ stimulating cardiomyocyte proliferation, ${ }^{24}$ and vascular regeneration. ${ }^{25}$

Our previous studies demonstrated the trophic effects of expanded ASC. ${ }^{18}$ However, the use of ASC in partial replacement of chondrocytes in ACI still needs isolation of adipose tissue by plastic adherence followed by cell expansion before joint surgery. SVF has the advantage that no expansion is required so that it could be easily incorporated into a single-step surgery. In this study, we have compared SVF and ASC as an alternative cell source for replacing part of the chondrocytes in a pellet coculture system and have evaluated cartilage formation in vivo in a nude mouse model after subcutaneous implantation. Our data suggested that SVF is a better source than ASC for a coimplantation strategy with primary chondrocytes in cartilage repair. The results of this study shed light on developing a one-step surgical procedure for the regeneration of focal cartilage defects using a mixture of SVF of adipose tissue and uncultured chondrocytes.

\section{Materials and Methods}

\section{Cell culture and expansion}

The use of all human materials in this study has been approved by the Medical Ethics Committee of the VU Medical Center (protocol number 2005/128) after obtaining informed consent. Human chondrocytes were obtained from macroscopically healthy-looking cartilage obtained from knee or hip biopsies of patients with end-stage osteoarthritis undergoing total knee or hip replacement. Cartilage biopsies were digested for $20-22 \mathrm{~h}$ in collagenase type II $(0.15 \%)$ dissolved in chondrocyte proliferation medium. The components of chondrocyte proliferation medium are DMEM (Dulbecco's minimal essential medium) supplemented with $10 \%$ FBS, $1 \times$ nonessential amino acids, $0.2 \mathrm{mM}$ ascorbic acid 2phosphate (AsAP), $0.4 \mathrm{mM}$ proline, $100 \mathrm{U} / \mathrm{mL}$ penicillin, and $100 \mu \mathrm{g} / \mathrm{mL}$ streptomycin. More details about chondrocyte isolation are described elsewhere. ${ }^{26}$

We defined human primary chondrocytes $(\mathrm{CH})$ in this article as chondrocytes with a low passage number (less than two passages) without immortalization. SVF of human adipose tissue was isolated from the abdominal fat pad of women, who underwent liposuction surgery, according to procedures in previous publications. ${ }^{27,28} \mathrm{SVF}$ were then seeded in culture flasks with MSC proliferation medium ( $\alpha$-MEM, minimal essential medium, supplemented with $10 \%$ fetal bovine serum, $1 \% \mathrm{~L}$-glutamine, $0.2 \mathrm{mM}$ ascorbic acid, $100 \mathrm{U} / \mathrm{mL}$ penicillin, $10 \mu \mathrm{g} / \mathrm{mL}$ streptomycin, and $1 \mathrm{ng} / \mathrm{mL}$ basic fibroblast growth 
factor, bFGF). Media were refreshed every 2 days to get rid of nonattached cells. When confluent, cells were trypsinized and passaged. The cells grown on tissue culture plastic were cultured to passage 2 before experimentation.

Expanded cells were called ASC in this article. All reagents used for cell culture were purchased from Gibco, Invitrogen, or unless otherwise stated. Common chemicals were purchased from Sigma-Aldrich.

\section{Pellet culture and chondrogenic differentiation}

For monocultures, 200,000 cells of $\mathrm{CH}, \mathrm{SVF}$, or ASC were seeded in one well of a round-bottom 96-well plate (non-tissue culture treated). For cocultures, 200,000 cells were seeded in a ratio of 4:1 (SVF/ASC: $\mathrm{CH})$. Cells were initially seeded in chondrocyte proliferation medium and centrifuged for $5 \mathrm{~min}$ at $500 \mathrm{~g}$. Medium was changed to chondrogenic differentiation medium (DMEM supplemented with $40 \mu \mathrm{g} / \mathrm{mL}$ of proline, $50 \mu \mathrm{g} / \mathrm{mL}$ ITS-premix ( insulin-transferrin-selenium), $50 \mu \mathrm{g} / \mathrm{mL}$ of AsAP, $100 \mu \mathrm{g} / \mathrm{mL}$ of sodium pyruvate, $10 \mathrm{ng} / \mathrm{mL}$ of transforming growth factor beta 3 , TGF $33,10^{-7} \mathrm{M}$ of dexamethasone, $500 \mathrm{ng} / \mathrm{mL}$ of bone morphogenetic protein (BMP)6, $100 \mathrm{U}$ penicillin $/ \mathrm{mL}$, and $100 \mu \mathrm{g} / \mathrm{mL}$ streptomycin) 1 day after seeding when stable pellets were formed. Cell pellets were cultured for 4 weeks before analysis.

\section{Monoclonal antibody labeling and flow cytometry}

The SVF (after one freeze-thaw cycle) and cultureexpanded ASC were analyzed for their cell surface marker expression using monoclonal antibodies $(\mathrm{mAb})$ against human CD29 (cat\# 555443), CD31 (cat\# 555445), CD34 (cat\# 345801), CD45 (Cat\# 555483), CD54 (cat\# 555511), CD73 (cat\# 550257), CD90 (cat\# 555595), CD105 (cat\# 560839), CD106 (cat\# 555647), CD117 (cat\# 555714), HLA-ABC (cat\# 555552), HLA-DR (cat\# 555581), and Lin1 (including CD3, CD14, CD16; CD19; CD20; CD56, cat\# 340546) (all from Becton Dickinson Biosciences), CD166 (ALCAM; cat\# MCA1926F, AbD SeroTec/MorphoSys), and CD271 (cat\# 130-098-103; Miltenyi Biotec BV, Bergisch Gladbach).

All monoclonal antibodies used were of the IgG1 type and either fluorescein isothiocyanate or phycoerythrin conjugated. Cells were washed with phosphate-buffered saline (PBS) and stained with specific antibodies for $30 \mathrm{~min}$ at $4^{\circ} \mathrm{C}$. Nonspecific fluorescence was determined by incubating cells with conjugated mAb anti-human IgG1 (BD Biosciences). Samples were washed twice and analyzed in a FACSCalibur flow cytometer (BD Biosciences) with the CellQuest Pro software (BD Biosciences).

\section{Histology}

Cell pellets were fixed with $10 \%$ formalin for $15 \mathrm{~min}$, dehydrated with ethanol, and embedded in paraffin using routine procedures. A microtome (Shandon) was used to cut $5 \mu \mathrm{m}$ thick sections. Slides were then deparaffinized and stained for sulfated glycosaminoglycans (GAG) with Alcian blue or Toluidine blue. Nuclei were counterstained with nuclear fast red.

\section{Quantitative GAG and DNA assays}

Cell pellets $(n=6)$ were washed with PBS and stored at $-80^{\circ} \mathrm{C}$ for $16-20 \mathrm{~h}$. Subsequently, they were digested in digestion buffer $(1 \mathrm{mg} / \mathrm{mL}$ proteinase $\mathrm{K}$ in Tris/EDTA buffer ( $\mathrm{pH} 7.6$ ) containing $18.5 \mu \mathrm{g} / \mathrm{mL}$ iodoacetamide and $1 \mu \mathrm{g} / \mathrm{mL}$ pepstatin A) for more than $16 \mathrm{~h}$ at $56^{\circ} \mathrm{C}$. GAG content was spectrophotometrically determined with 1,9Dimethyl-Methylene Blue chloride (DMMB) staining in PBE buffer (phosphate buffer with ethylenediaminetetraacetic acid) (14.2 g/L Na${ }_{2} \mathrm{HPO}_{4}$ and 3.72 g/L Na${ }_{2}$ EDTA, pH 6.5) using an ELISA (enzyme-linked immunosorbent assay) reader (TECAN) at an absorbance of $520 \mathrm{~nm}$ with chondroitin sulfate as a standard. Cell numbers were determined by quantification of total DNA using a CyQUANT DNA Kit (Molecular Probes).

\section{Immunohistochemical staining}

For immunohistochemistry, sections were deparaffinized, incubated with $3 \%$ hydrogen peroxide, and blocked in $1 \%$ bovine serum albumin and $1.5 \%$ normal goat serum. Slides were subsequently incubated overnight at $4{ }^{\circ} \mathrm{C}$ with mouse monoclonal antibodies against COL II (Cat\# MAB1330; Novagen). Sequentially, primary antibodies were visualized by EnVision Detection Systems (Dako). Counterstaining was performed with Hematoxylin.

\section{RNA isolation and quantitative PCR}

RNA samples of cell pellets were isolated with the NucleoSpin RNA II Kit (MACHEREY-NAGEL). Total RNA was reverse transcribed into cDNA using the iScript cDNA Synthesis Kit (Bio-Rad). Quantitative PCR (qPCR) was performed on cDNA samples using the iQ SYBR Green Supermix (Bio-Rad). PCR was carried out on MyiQ2 TwoColor Real-Time PCR Detection System (Bio-Rad) under the following conditions: cDNA was denatured for $5 \mathrm{~min}$ at $95^{\circ} \mathrm{C}$, followed by 45 cycles consisting of $15 \mathrm{~s}$ at $95^{\circ} \mathrm{C}, 15 \mathrm{~s} 60^{\circ} \mathrm{C}$, and $30 \mathrm{~s}$ at $72^{\circ} \mathrm{C}$. For each reaction a melting curve was generated to test the primer dimer formation and nonspecific priming. The sequences of primers for real-time PCR are listed in Supplementary Table S1 (Supplementary Data are available online at www.liebertpub.com/tea). Calculation of Relative Expression was performed with Bio-Rad iQ5 optical system software (version 2.0) using the double delta $\mathrm{Ct}$ method. ${ }^{29}$ GAPDH primers were used for normalization.

\section{Microarray processing and statistical analysis}

Three donors of SVF were used for the microarray study. Cells from the same three donors were expanded in vitro for two passages to obtain ASC. ASC of passage 2 were cyropreserved in liquid nitrogen. The RNA of both SVF and ASC were isolated from the cells immediately after thawing from liquid nitrogen. RNA extraction was performed as previously described. The NuGEN Ovation PicoSL WTA System Kit followed by Encore BiotinIL module were utilized for synthesizing biotinylated sscDNA starting from $50 \mathrm{ng}$ of total RNA. Obtained samples (750 ng) were then hybridized onto Illumina HumanHT-12 v4 Expression BeadChip. Chips were scanned by the Illumina iScan array scanner. Illumina's GenomeStudio v. 2010.3 software was applied to analyze gene expression profiling using the default settings advised by Illumina.

Raw data of fluorescence intensity were normalized by quantile normalization. ${ }^{30}$ Differential gene expression was analyzed by the commercial software package GeneSpring, version 11.5.1. (Agilent Technologies). Genes with at least 
two-fold difference and being significantly differentially expressed according to a one-way ANOVA with a Benjamini-Hochberg FDR correction and Tukey's HSD post hoc test using a cut-off rate of $p \leq 0.05$ were selected. Changes of gene expression in annotated canonical pathways and biofunctions were analyzed using ingenuity pathway analysis software (Ingenuity Systems). Search Tool for the Retrieval of Interacting Genes/Proteins (STRING) was used to predict possible protein-protein interaction (PPI) networks, ${ }^{31}$ with a threshold cutoff of a combined score $>0.4$.

Clusters were formed using a k-means clustering algorithm. The differentially expressed genes between SVF and ASC with possible PPI were then visualized by constructing a PPI network using Cytoscape software (version 3.2.1, http://cytoscape.org/). ${ }^{32}$ In the PPI network, each node represented one protein of a differentially expressed gene, the edge represented interaction, and the connectivity degree of a node was defined as the number of interactions between this node and its surrounding nodes.

\section{Cell tracking with organic fluorescent dyes}

The organic fluorescent dye CM-DiI (Molecular Probes) was used for cell tracking in cocultures. Cells were labeled according to the manufacturer's protocol. Briefly, cells were trypsinized and resuspended in PBS at a concentration of $2 \times 10^{6}$ cells $/ \mathrm{mL}$. The cells were incubated with $4 \mu \mathrm{M}$ of CM-DiI at $37^{\circ} \mathrm{C}$ for $5 \mathrm{~min}$ followed by incubation at $4^{\circ} \mathrm{C}$ for $15 \mathrm{~min}$. Cells were washed with PBS and applied in coculture experiments.

\section{5-ethynyl-2 -deoxyuridine labeling and staining}

Cell proliferation in pellets was examined with the Click$\mathrm{iT}^{\circledR}$ EdU Imaging Kit (Molecular Probes). Cell pellets were cultured in chondrogenic differentiation medium containing $10 \mu \mathrm{M}$ EdU (5-ethynyl-2'-deoxyuridine) for $24 \mathrm{~h}$ before harvesting. At day 2, cell pellets were washed with PBS and fixed with $10 \%$ formalin for $15 \mathrm{~min}$. Sections of $10 \mu \mathrm{m}$ were cut with a cryotome (Shandon). Sections were permeabilized with $0.5 \%$ of Triton X-100 for $20 \mathrm{~min}$ and stained for EdU with Alexa-488 cocktail. Nuclei were counterstained with Hoechst 33342 (provided in the same kit).

\section{Image acquisition and analysis}

Histological images were made with a Nikon E300 microscope. Fluorescent images were taken with a BD pathway 435 confocal microscope (BD Biosciences). Details of image quantification are published elsewhere. ${ }^{16}$ Using montage capture, images of high resolutions were obtained covering the entire section of a pellet. Separate images were captured using BP536/40 (Alexa-488), BP593/40 (DiI), and LP435 (Hoechst 33342) and pseudocolored green, red, and blue, respectively. ImageJ software ${ }^{33}$ was used for cell counting.

Briefly, we manually set a threshold to avoid artifacts. The number of green cells, red cells, green and red overlapping cells (two colors overlapped), and total cells were counted by running plug-ins written in macro language of ImageJ (available on request). Values represent the mean \pm standard deviation of at least three biological replicates. To determine the percentage of EDU-positive chondrocytes, SVF or ASC cells in coculture pellets, calculation was carried out as follows: percentage of EDU-positive chondrocytes $=$ overlapped cells $\div$ red cell $\times 100 \%$; percentage of EdU-positive SFV $=$ (green cells-overlapped cells) $\div$ (total cells-red cells); percentages of EdU-positive $\mathrm{ASC}=$ (green cells-overlapped cels $) \div$ (total cells-red cells). Since chondrocytes were labeled with red fluorescence, we assumed all nonred cells were SVF or ASC. The actual ratio of red: nonred cells also reflected the input ratio of 1:4 of chondrocyte: SVF/ASC

\section{Short tandem repeats analysis}

Genomic DNA samples were extracted from pellets with the QIAamp DNA Mini Kit (Qiagen). The sixteen loci of the PowerPlex 16 System (Promega) were amplified, typed, sequenced, and analyzed by ServiceXS BV. Specific alleles for the donor of SVF or ASC and the donor of CHs were identified. These alleles were used to define the origin of cells in allogeneic coculture of SVF/ASC and CH after 4 weeks. The amount of DNA present for each donor was calculated from the areas of the electropherogram for each locus of SVF or ASC and $\mathrm{CH}$-specific alleles and the ratio was determined.

\section{Implantation of cells incorporated in alginate gel into nude mice}

All animal experiments were approved by the local Animal Care and Use Committee of the University Medical Center, Utrecht (approval no. 104231) and were performed according to the Dutch legislation. Pools of SVF or ASC were made by mixing cells from three donors. $\mathrm{CH}$ from another three donors were mixed to make a pool of $\mathrm{CH}$. Then, pools of SVF or ASC were mixed with the pool of $\mathrm{CH}$ in a ratio of $4: 1$, and then resuspended in $2 \%$ alginate in PBS at a density of $1 \times 10^{7}$ cells $/ \mathrm{mL}$. Coimplantation constructs were made by transferring $70 \mu \mathrm{L}$ of alginate cell suspension to $100 \mu \mathrm{L}$ of a $100 \mathrm{mM} \mathrm{CaCl}_{2}$ solution and jellifying for $5 \mathrm{~min}$ at $37^{\circ} \mathrm{C}$.

Constructs were washed with PBS and MSC proliferation medium ( $\alpha$-MEM supplemented with $10 \%$ fetal bovine serum, $1 \%$ L-glutamine, $0.2 \mathrm{mM}$ ascorbic acid, $100 \mathrm{U} / \mathrm{mL}$ penicillin, $10 \mu \mathrm{g} / \mathrm{mL}$ streptomycin, and $1 \mathrm{ng} / \mathrm{mL}$ bFGF. Constructs with only chondrocytes at a density of $1 \times 10^{7}$ cells $/ \mathrm{mL}$ served as positive control, whereas blank constructs without any cells were negative controls. For each condition $(\mathrm{SVF}+\mathrm{CH}$, $\mathrm{ASC}+\mathrm{CH}, \mathrm{CH}$ and blank), 10 constructs were made 1 day before the surgery and cultured in chondrocyte proliferation medium (DMEM supplemented with $10 \%$ FBS, $1 \times$ nonessential amino acids, $0.2 \mathrm{mM}$ ascorbic acid 2-phosphate, $0.4 \mathrm{mM}$ proline, $100 \mathrm{U} / \mathrm{mL}$ penicillin, and $100 \mu \mathrm{g} / \mathrm{mL}$ streptomycin).

Before the implantation, ten 6-week-old male BALB/C nude mice (Experimental Animal Center, Utrecht) were anesthetized with isoflurane with dosage of $2 \%$ for maintenance and up to $5 \%$ for induction in oxygen from a precision vaporizer. Then, four subcutaneous pockets were made on the back of a mouse. One construct was put in one pocket. The locations of the constructs were randomized and recorded. At 8 weeks postimplantation, mice were euthanized using $\mathrm{CO}_{2}$ in a dedicated chamber, and implanted constructs were then carefully separated from the surrounding fibrous capsule, and washed in PBS for histological analysis and quantitative GAG analysis.

\section{Statistical analysis}

GAG and DNA quantifications were examined for statistical significance with one-way analysis of variance (ANOVA) 
followed by Tukey's HSD (Honest Significant Difference) Test. Statistical analysis of EdU-positive cells was made by using the Student's $t$ test. $p$ values of $<0.05$ were considered as statistically significant.

\section{Results}

\section{Comparisons of surface marker profiles} and chondrogenic potential of SVF and ASC

We first performed fluorescence activated cell sorting (FACS) to analyze the profiles of CD markers of the SVF and ASC. Representative flow histograms are shown in Figure 1A. The mean percentages of positive cells are displayed in Figure 1B. The SVF fraction contained a subset of cells that were positive for the endothelial cell-associated marker CD31, and the stem cell marker CD34. ${ }^{34,35}$ The hematopoietic lineageassociated marker CD45 was weakly present in SVF; however, the CD45-positive cells could not be distinguished as a subpopulation from SVF. As expected, ASC did not express these markers. A fraction of the initial SVF cell population expressed stromal cell-associated markers. Only $10 \%$ of the SVF expressed CD105, whereas 86\% of the SVF expressed CD90; the levels of CD29, CD166, and CD105 were intermediate to these values.

After isolation of ASC by expansion in vitro, the percentage of cells staining positive for each of these markers increased. The initial SVF also contained a subpopulation of cells positive for stem cell-associated markers. An average of $69 \%$ of the SVF expressed the stem cell marker CD34. Its level declined to $0.4 \%$ in ASC. Expressions of CD73 increased from approximately 50\% in SVF to nearly $100 \%$ in ASC. In general, ASC contained a more homogenous cell population, which was CD31, CD34, and CD45 negative, but positive for MSC markers like CD105 and CD166. In line with our expectation, SVF represented a heterogeneous cell population containing not only cells with typical MSC characteristics, but also CD $31^{+}$ endothelial progenitors, a minority of slightly positive $\mathrm{CD} 45^{+}$ hematopoietic cells and CD34 ${ }^{+}$stem cells.

Then, the chondrogenic differentiation potential of SVF and ASC was characterized by putting them in pellet culture. ASC generally formed better aggregates than SVF. We tested nine donors individually. Every donor we tested could give rise to ASC that formed stable pellets, while only six out of nine donors we tested provided SVF that formed stable pellets. Results from histology and GAG quantification (Fig. 1C, D) showed that pellets from ASC produced matrix containing more GAGs than SVF.

\section{Chondrocytes cocultured with SVF produce more GAG than with ASC}

To compare the effect of ASC with SVF derived from the same donor on chondrocyte pellet cocultures, both cell fractions were cocultured with primary human chondrocytes at passage $2(\mathrm{P} 2)$ in pellets $(\mathrm{SVF}+\mathrm{CH}$ and $\mathrm{ASC}+\mathrm{CH})$ in a ratio of $4: 1$. Monocultures of chondrocytes $(\mathrm{CH})$ served as control. Three chondrocyte donors were randomly matched to nine SVF and ASC donor pairs. Results of histology from one representative experiment are shown in Figure 2A. In contrast to pellet monocultures of SVF, in combination with primary human chondrocyte, SVF of all 9 donors formed stable cell pellets. Alcian blue and Toluidine blue staining indicated the presence of GAG in all experimental groups. The staining appeared more intense in the $\mathrm{SVF}+\mathrm{CH}$ group.
The presence of collagen type 2 was confirmed in all coculture and monoculture groups using immunohistochemistry. $\mathrm{CH}$ group had the most intensive staining, while $\mathrm{ASC}+\mathrm{CH}$ group had the least expression of COL2A1. The intensity of $C O L 2 A 1$ staining in $\mathrm{SVF}+\mathrm{CH}$ group was intermediate of the other two groups. Overviews of these staining on whole pellets are shown in the insets of Figure 2A. Previously, we showed that GAGs were mainly produced by chondrocytes in coculture pellets. ${ }^{16,18}$ When comparing the GAGs between two coculture groups, we ought to eliminate the variant of different donors of chondrocyte, since we focus on donor variation of ASC/SVF. Therefore, instead of using $\mu \mathrm{g}$ for GAG quantification, relative values of total GAG and GAG/DNA in coculture groups were obtained by dividing absolute values of total GAG or GAG/DNA in coculture groups by to absolute values of the same in chondrocyte $(\mathrm{CH})$ monoculture groups.

Data from nine SVF or ASC donors are averaged and displayed in Figure 2B. SVF+CH group significantly showed higher capacity in producing GAG than the $\mathrm{ASC}+\mathrm{CH}$ group. Expression of chondrogenic genes at week 4 of coculture were examined by qPCR (Fig. 2C-E). Expression of collagen $2 a 1$ (COL2al), collagen 9a1 (COL9a1), and aggrecan $(A C A N)$ mRNA tended to be higher in the $\mathrm{SVF}+\mathrm{CH}$ group, but this did not reach significance.

\section{Coculture of chondrocytes with SVF and ASC induces chondrocyte proliferation}

Our previous data showed that proliferation of cells in coculture pellets mainly occurred in the first few days. ${ }^{16}$ EdU (5-ethynyl-2'-deoxyuridine) incorporation and cell tracking were used to investigate cell proliferation in the coculture pellets at day 2 after cell seeding. EDU-positive cells were detected in all groups (Fig. 3A left panel). Quantitative data are shown in Figure 3B and C. Percentages of EdU-positive chondrocytes in coculture pellets tended to be higher in coculture pellets with SVF than with ASC, but this did not reach significance most likely due to large inter-donor variation (Fig. 3B). After 2 days of culture, the percentage of EdUpositive SVF or ASC in coculture pellets also did not differ (Fig. 3C).

Previously, we have shown that coculture of primary chondrocytes with bone marrow MSCs induces massive cell death of the latter after 1 week. ${ }^{16}$ Therefore, a fluorescent TUNEL assay was performed to determine apoptotic cells in coculture pellets at the end of week 1 . High numbers of TUNEL-positive cells were found in cell pellets containing SVF or ASC, but very few in pellet monocultures of chondrocytes (Fig. 3A right panel). TUNEL staining was significantly higher in SVF coculture pellets than in ASC coculture pellets (Fig. 3D). Since cell tracking using organic fluorescent dye did not last for 2 weeks, ${ }^{16}$ we measured the overall apoptotic cells per pellet instead of the percentage of apoptotic individual cell types in coculture pellets.

After 4 weeks of coculture, short tandem repeats (STR) analysis was performed to determine the ratio of cells derived from chondrocytes or from either SVF or ASC donors. The distinguishable loci between chondrocytes and SVF/ ASC donors were selected and averaged. In SVF coculture pellets, the initial seeding ratio of 4:1 (SVF: chondrocytes) was changed to almost $60 \%$ chondrocytes and $40 \%$ SVF 
A
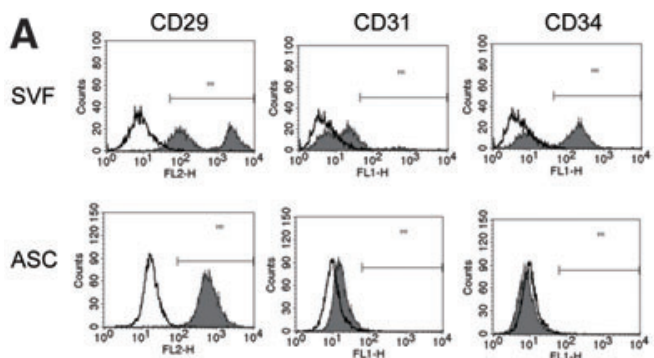

SVF

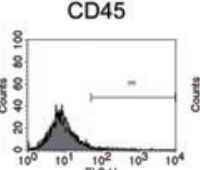

ASC
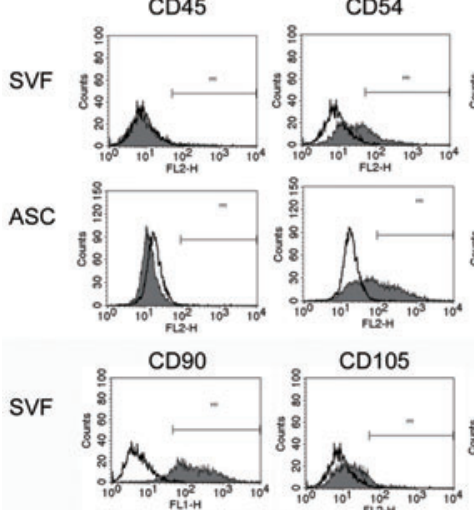

ASC
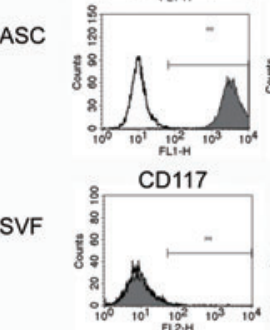

ASC
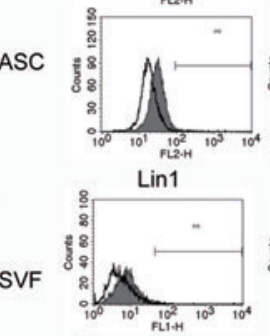

ASC
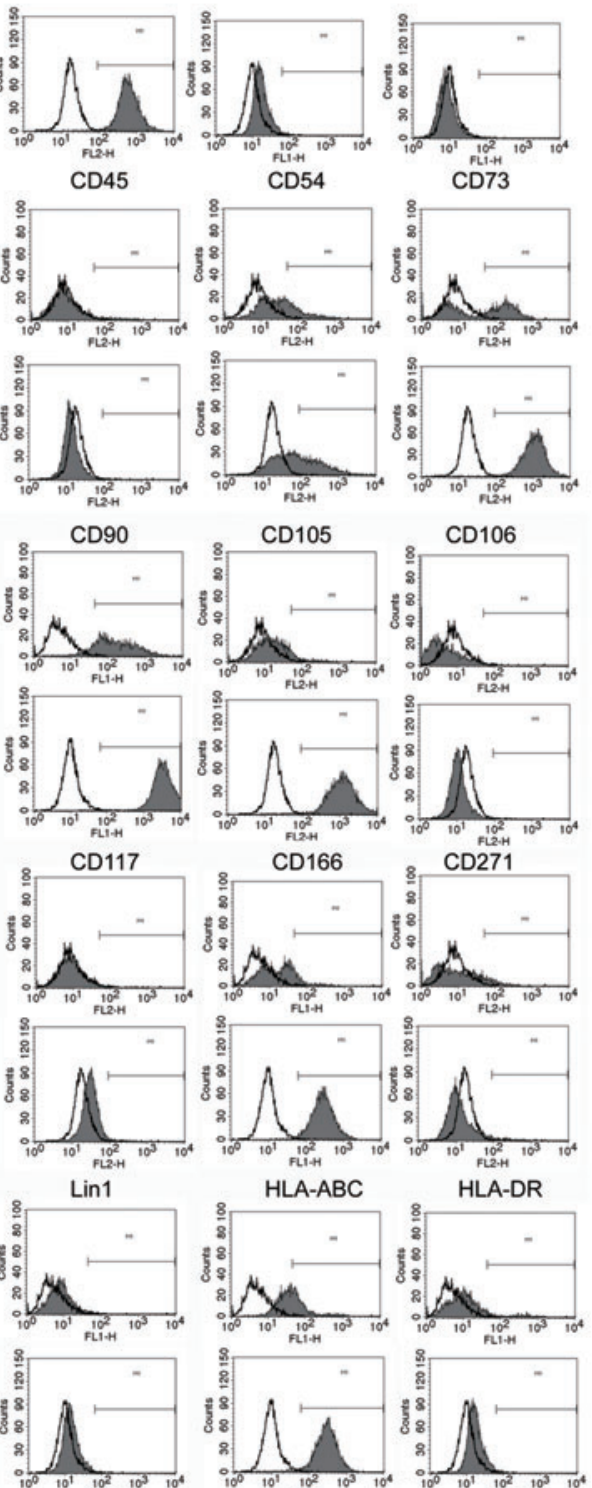

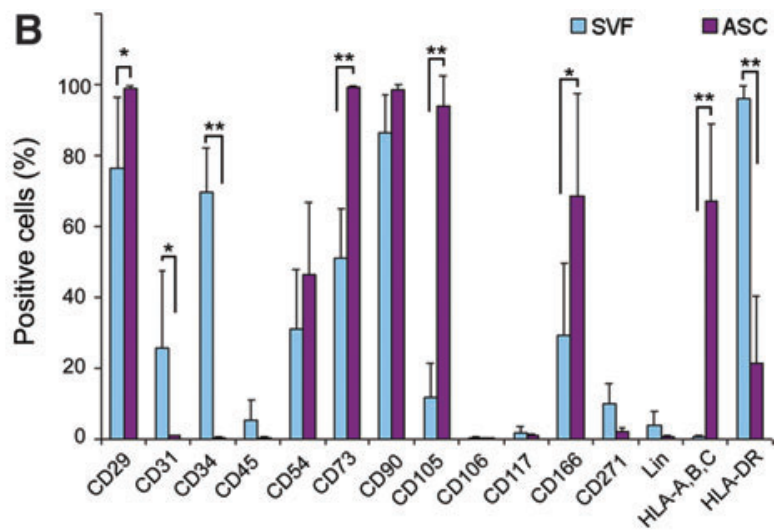

C

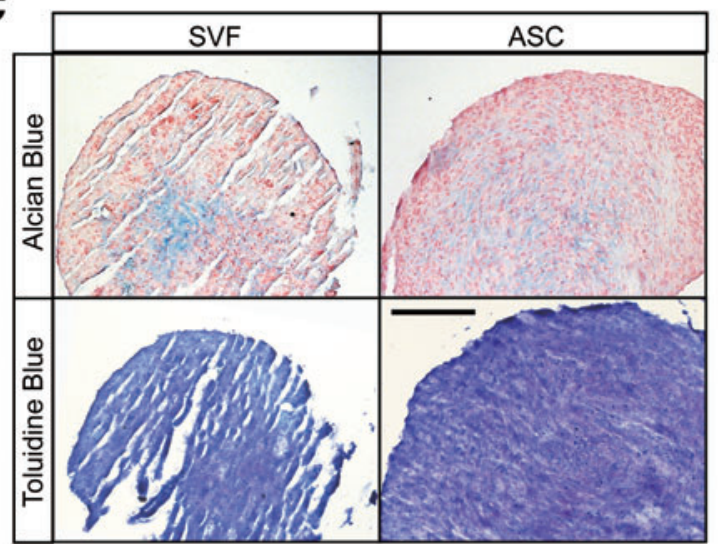

D

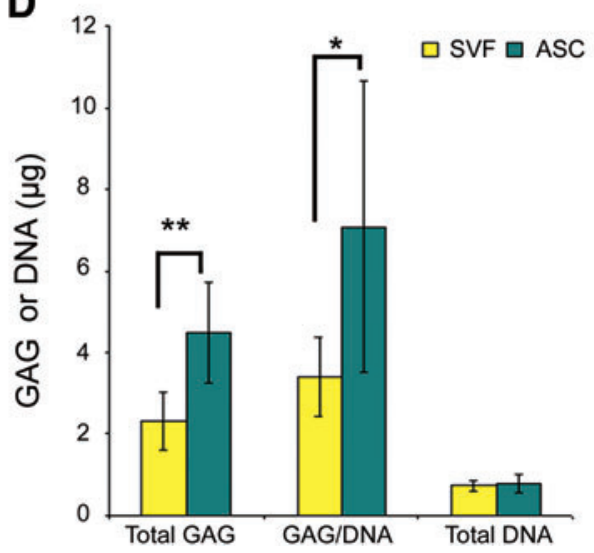

FIG. 1. Comparison of surface marker profiles and chondrogenic potential between stromal vascular fraction (SVF) and adipose stem cell (ASC). (A) FACS was performed to analyze the profile of the expression of CD markers on SVF and ASC. Histograms from one representative donor pair of SVF and ASC are shown. Lines are isotypes, filled graphs indicate specific binding of antibodies. Of each cell fraction at least 100,000 cells were analyzed. (B)\% of positive cells for each CD marker was calculated based on the average of nine donor pairs of SVF and ASC. Asterisk represents $p<0.05$. Double asterisks represent $p<0.01$. NS $=$ Not Significant. Error bar reflects Standard Deviation (SD). Statistical analysis is done by Student's $t$-test. (C) Chondrogenic potential of SVF and ASC is illustrated by histological staining. 200, 000 cells of SVF or ASC were seeded per well in a round bottom nonadherent 96-well plate. Cell pellets were made by centrifuge at $500 \mathrm{~g}$ for $3 \mathrm{~min}$. Then pellets were cultured in chondrogenic differentiation medium for 4 weeks. Scale bar $=100 \mu \mathrm{m}$. Results of a representative donor pair of which SVF formed a stable pellet is shown. (D) At 4 weeks of chondrogenic differentiation glycosaminoglycan (GAG) and DNA in the cell pellets were quantified. Data represent the average of five donor pairs of SVF, which formed stable pellets, and ASC. Asterisk represents $p<0.05$. Double asterisks represent $p<0.01$. Error bar reflects Standard Deviation (SD). Statistical analysis is done by Student's $t$-test. Color images available online at www.liebertpub.com/tea 

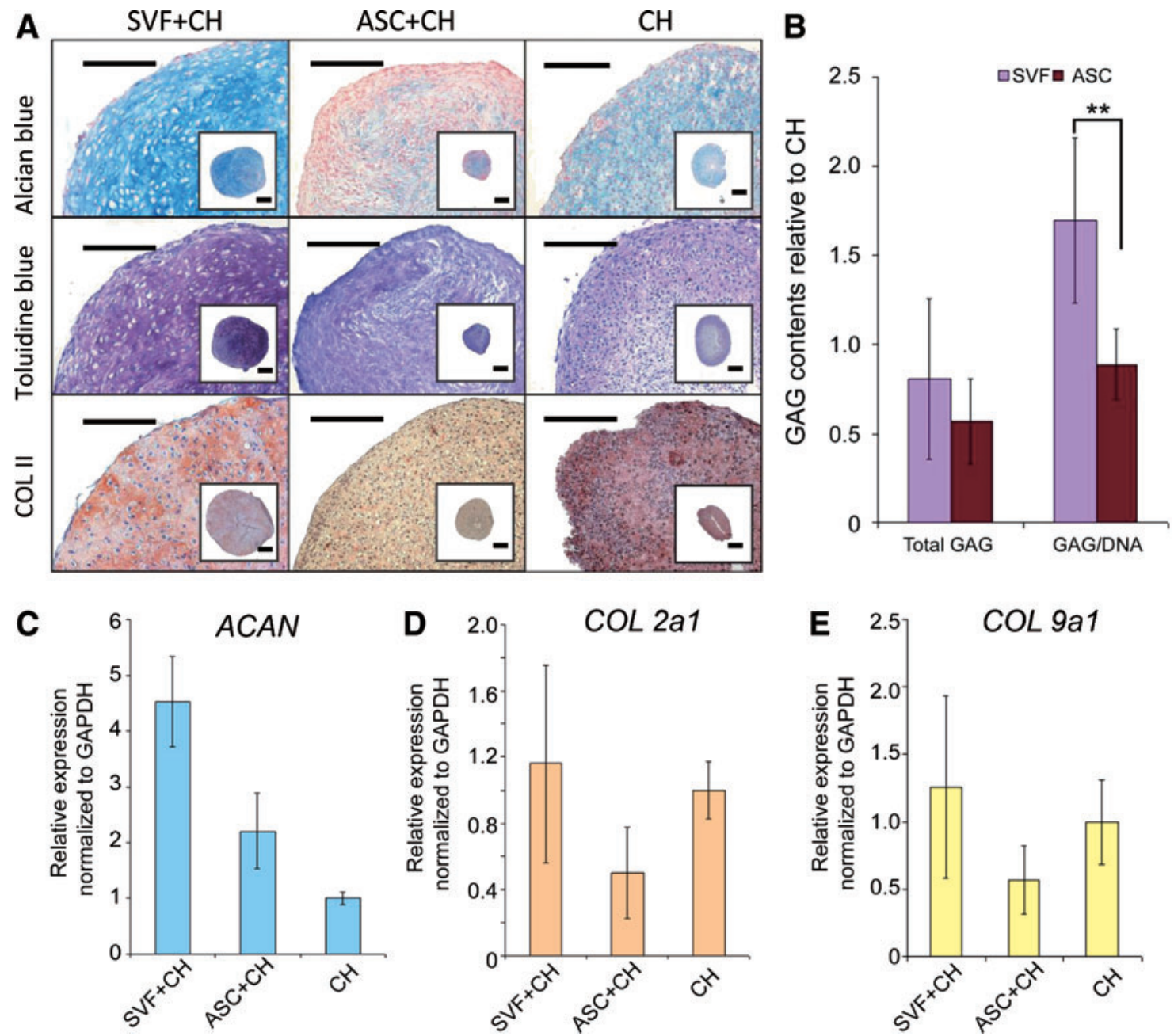

FIG. 2. Coculture of chondrocytes with SVF or ASC-enhanced cartilage matrix formation. (A) Alcian blue and Toluidine blue staining indicated the presence of GAGs. Immunohistochemical staining showed expression of collagen type II. Cell pellets were cultured in chondrogenic differentiation medium (as described in Materials and Methods section) for 4 weeks before examination. Scale Bar $=100 \mu \mathrm{m}$. Results of a representative donor pair is shown. (B) GAG quantification showed that the $\mathrm{SVF}+\mathrm{CH}$ group produced more GAG than the ASC+CH group. Data represent the average of nine donor pairs of SVF (or ASC) with chondrocytes. Values are relative to pellet monoculture of chondrocytes $(\mathrm{CH})$. $p$ value was calculated by Student's $t$-test. Error bar reflects SD. Double asterisks represents $p<0.01$. (C-E) Expression levels of $A C A N(C), C O L 2 a 1$ (D), and COL9al (E) mRNA were examined by qPCR. RNA samples were extracted from nine donor pairs of SVF and ASC with chondrocytes, from pellets cultured in chondrocyte proliferation medium for 4 weeks. RNA was isolated from three pellet cultures per condition. Relative expression levels were obtained by normalization to GAPDH. Values represent the relative gene expression compared to monoculture of chondrocytes $(\mathrm{CH})$. Error bar reflects SD. Color images available online at www.liebertpub.com/tea

after 4 weeks of culture. The seeding ratio in the ASC coculture pellets after 4 weeks of culture $(75 \%$ ASC and $25 \%$ chondrocytes) did not significantly deviate from the initial seeding ratio of 4:1 (ASC: chondrocytes) (Fig. 3E). Increased cell death of SVF cell fractions in combination with a larger stimulatory effect on chondrocyte proliferation are most likely responsible for the relative overgrowth of the primary chondrocytes in the coculture pellets with SVF.

\section{Comparison of global gene expression profiles between SVF and ASC}

We have shown that trophic factors of bone marrowderived MSCs are responsible for increased chondrocyte proliferation and matrix deposition in coculture pellets with chondrocytes. ${ }^{16} \mathrm{We}$, therefore, compared the global gene expression profile of pairs of SVF and ASC to identify differentially expressed genes between both cell populations using a microarray experiment. As shown in Figure 4A, the majority of genes that can be detected in either cell type fall in the region of two-fold change (up or down, yellow dots). Eighty genes were found >two-fold upregulated (red dots) in SVF, whereas 48 genes were >two-fold downregulated (blue dots). Differential expression of a random selection of genes was validated using qPCR (Fig. 4B, C).

Some variation in absolute fold change as determined by microarray or qPCR was observed, however, the trends were the same. A complete list is given in Supplementary 

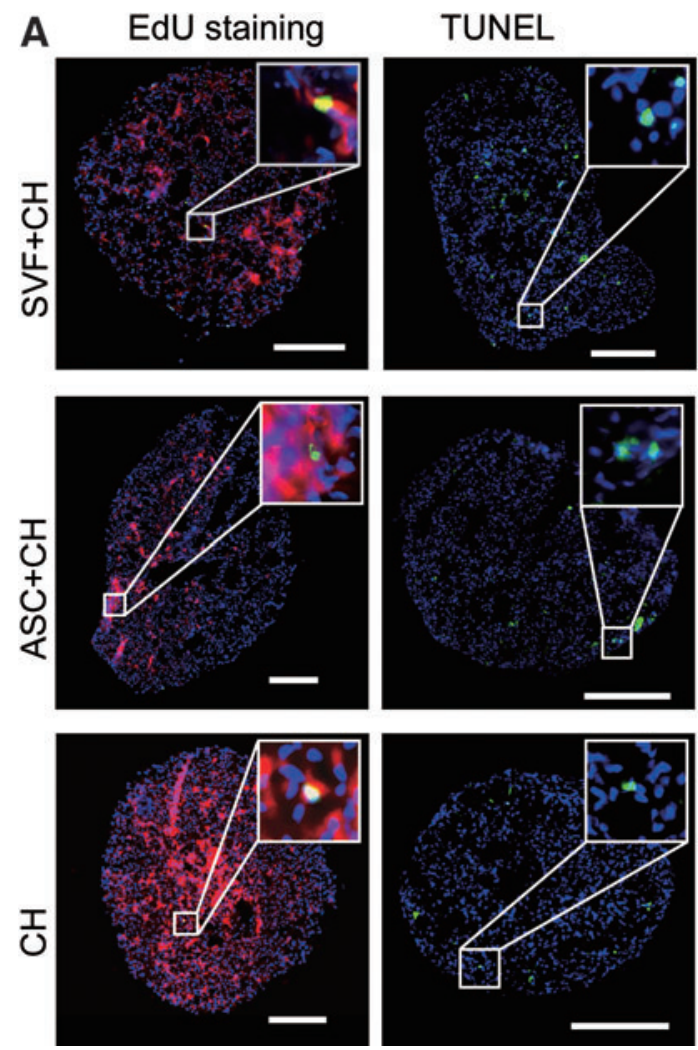

TUNEL
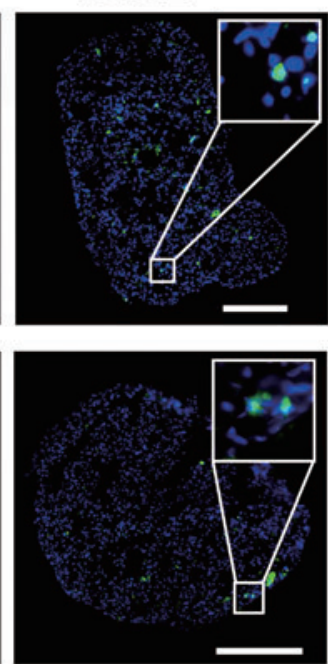
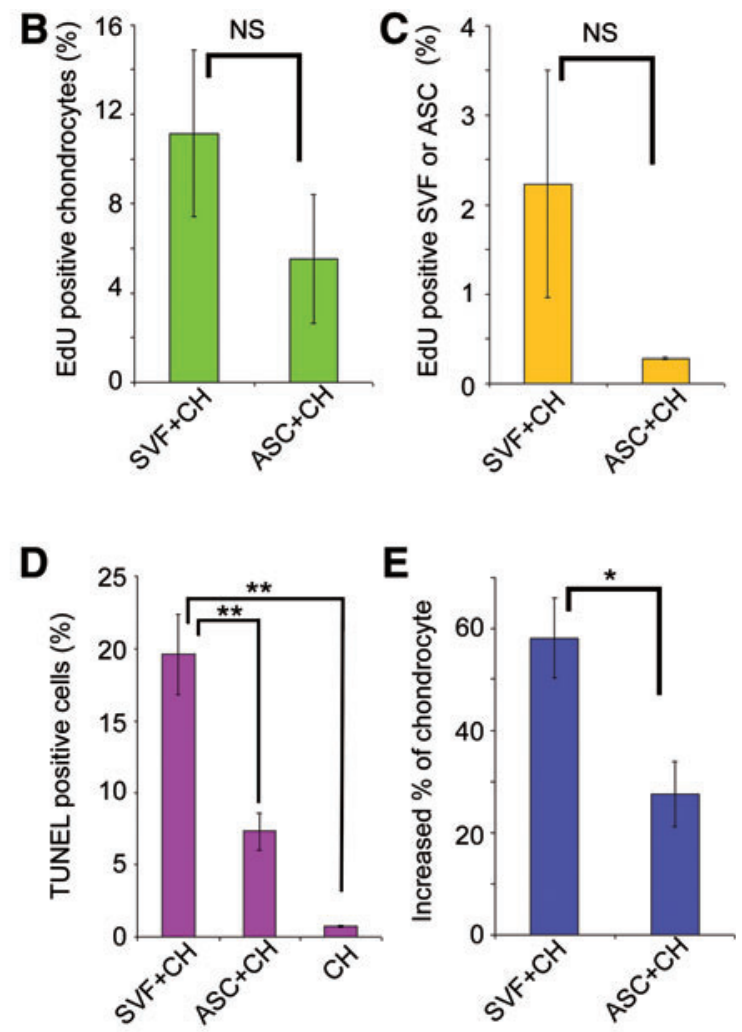

FIG. 3. Coculture induces apoptosis of MSCs and proliferation of chondrocytes. (A) Left panel: EdU staining of pellets at day 2 after seeding. PCs were labeled with CM-DiI (red). EdU incorporation into newly synthesized DNA was visualized by Alexa-488 (green). Nuclei were counterstained with Hoechst 33342 (blue). Right panel: TUNEL staining of pellets were performed at 1 week after seeding. TUNEL-positive cells were visualized with fluorescent labeling (green). Nuclei were counterstained with Hoechst 33342 (blue). Scale bar $=100 \mu \mathrm{m}$. A representative picture of 1 ASC or SVF donor is shown. Inserts showed the boxes in higher magnification. (B) Quantification of EdU-positive chondrocytes. Three pellets for each donor pair of SVF or ASC and chondrocytes were analyzed. Data represent the average of three donor pairs. Values expressed relative to monoculture of chondrocytes. Asterisk represents $p<0.05$. Double asterisks represent $p<0.01$. NS $=$ Not Significant. Error bar reflects SD. (C) Quantification of EdU-positive SVF or ASC. Three pellets for each donor pair of SVF or ASC and chondrocytes were analyzed. Data represent the average of 3 donor pairs. Asterisk represents $p<0.05$. Double asterisks represent $p<0.01$. NS = Not Significant. Error bar reflects SD. (D) Quantification of TUNEL-positive cells. Three pellets for each donor pair of SVF or ASC and chondrocytes were analyzed. Data represent the average of three donor pairs. Asterisk represents $p<0.05$. Double asterisks represent $p<0.01$. NS $=$ Not Significant. Error bar reflects SD. (E) STR analysis was performed on genomic DNA isolated from coculture pellets of SVF or ASC and chondrocytes at an initial seeding ratio of 80:20 after 4 weeks of culture. Only informative loci that could discriminate between the SVF or ASC donor and PCs were taken into account. Averages of these loci were calculated to indicate the ratio of SVF or ASC and chondrocytes after coculture. Data represent an average of three donor pairs. Asterisk represents $p<0.05$. Error bar reflects SD. Color images available online at www.liebertpub.com/tea

Table S2 showing all upregulated and downregulated genes with a more than two-fold change and a $p$-value $<0.05$ as determined by a one-way ANOVA corrected for a BenjaminiHochberg FDR and Tukey's HSD post hoc test. As a result of the heterogeneous populations, genes higher expressed in SVF than in ASC are a combination of markers found in endothelial cells (e.g., EFNB2), adipocytes (e.g., APOD, FABP4), and lymphocytes (e.g., LTA, LITAF).

On the other hand, ASC showed higher expression of genes of the mesenchymal cell lineages when compared to SVF. These genes included DKK3, TGFBI, GREM1, and SFRP2 that are expressed in chondrocytes, ${ }^{36-38}$ and COL1A1, SPARC, and POSTN that are expressed in osteoblasts. ${ }^{39,40}$ Roughly, one third of these differentially expressed genes are secreted factors, as shown in Table 1.
Some of the genes together with others (NFKB1 and $U B D$ ) on the top of the differentially expressed gene list were selected for qPCR validation (Fig. 4B, C). Variations between the data obtained from microarray and qPCR were observed, however, the trends were the same.

The list of all upregulated and downregulated genes with more than two-fold change was then imported into ingenuity pathway analysis software to identify differential expression between SVF and ASC in annotated canonical pathways and biofunctions. Significantly changed pathways were diseases and disorders (Supplementary Fig. S1), molecular and cellular functions (Supplementary Fig. S2), and physiological system development/function (Supplementary Fig. S3). In addition, the differentially expressed genes were used as input into Search Tool for the Retrieval of Interacting 
A

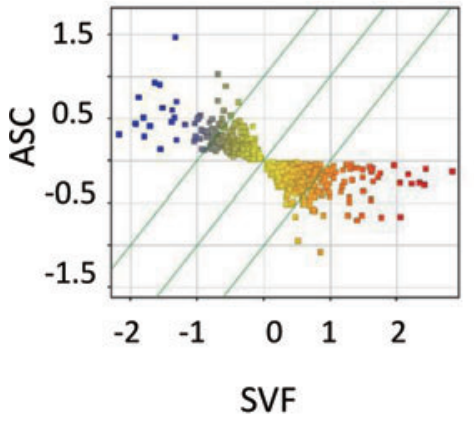

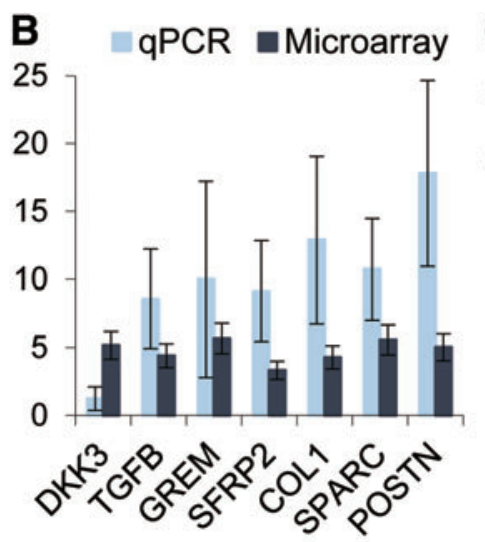

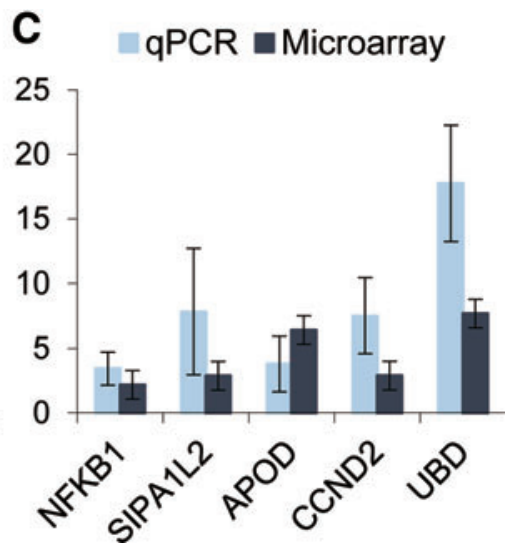

FIG. 4. Comparison of global gene expression profiles of SVF and ASC. (A) RNA samples were isolated from SVF or ASC of three donor pairs and applied in a microarray study. The average ratio of gene expression in SVF over ASC is plotted. Green lines indicate thresholds for up (>two-fold) and downregulated gene expression ( $<$ two-fold). In red are genes depicted which are $>$ two-fold upregulated in SVF. In blue are genes depicted which are $>$ two-fold downregulated in SVF. (B) Expression levels of genes that were upregulated in SVF were validated by qPCR. The values are expressed relative to ASC and represent the mean of three donors. (C) Expression levels of genes that are upregulated in ASC were validated by qPCR. The values were relative to SVF and represent the mean of three donors. Error bar reflects SD. Color images available online at www.liebertpub.com/tea

Genes/Proteins to identify predicted interaction networks of genes and/or proteins (Supplementary Fig. S4).

The results show three major clusters of interacting proteins. The first one (red) is a group of secreted factors centered by FNI and TGFBI, most of which are produced by cells from the mesenchymal lineage to regulate the differentiation and proliferation of chondrocytes. One cluster (brown) of extracellular matrix (ECM) components centered on COL1A2 is also found. The third major cluster (yellow) is a group of transcription factors and cytokines, which is regulated by $N F K B 1$.

\section{Ectopic cartilage formation of SVF and ASC mixed with chondrocytes}

To evaluate our previous findings in vivo, mixtures of chondrocytes and SVF or ASC (ratio 1:4) were incorporated in an alginate gel and subcutaneously implanted in immunotolerant mice. ${ }^{41}$ Eight weeks after implantation, there was a significant accumulation of ECM components in the pericellular area in all experimental groups. $\mathrm{SVF}+\mathrm{CH}$ group produced most ECM in comparison with the other two groups according to the color of the staining (Fig. 5A left and middle panels).

Immunohistochemical staining indicated the presence of more collagen type 2 protein expression in engineered cartilage of $\mathrm{SVF}+\mathrm{CH}$ than in $\mathrm{ASC}+\mathrm{CH}$ (Fig. 5A right panel). Results of GAG assay confirmed that $\mathrm{SVF}+\mathrm{CH}$ group contained more GAG than the other two groups (Fig. 5B). The quantification of DNA in the constructs showed that $\mathrm{SVF}+\mathrm{CH}$ had fewer cells (Fig. 5C). These data suggested that the SVF mixed with chondrocyte produced more cartilage matrix than ASC in vivo.

\section{Discussion}

In previous reports, we have shown that coculture of MSCs and $\mathrm{CH}$ in pellets augmented cartilage matrix for- mation. This effect can be largely attributed to a trophic effect of the MSCs that increases the proliferation and matrix formation by chondrocytes, rather than by chondrogenic differentiation of MSCs. We furthermore showed that this trophic effect of MSCs is a general feature that can be observed in MSCs from multiple sources like bone marrow, adipose tissue, and synovium. ${ }^{18}$

In this study, we investigated for the first time the trophic effects of SVF of adipose tissue. We show that the SVF is a better cell source than ASC in facilitating cartilage formation in coculture with chondrocytes. This conclusion is based on the following observations; (1) Coculture pellets of SVF and chondrocytes produced more GAG than pellets of ASC and chondrocytes, (2) the proportion of chondrocytes after coculturing is more increased in coculture pellets of SVF and chondrocytes than pellets of ASC and chondrocytes, (3) mixtures of SVF and chondrocytes deposit more GAG and collagen type 2 than that of ASC and chondrocytes in an ectopic cartilage formation model in nude mice.

For the first time, we showed in this study that SVF cells could act as trophic mediators in coculture pellets with chondrocytes. We previously reported that expanded cells isolated from SVF (adipose-derived MSCs) could induce chondrocyte proliferation in coculture pellets and promoted GAG formation in cocultures. ${ }^{18}$ In this study, we showed that in comparison to ASC, SVF from the same donor were more potent in promoting GAG formation in cocultures. The proliferation rate of chondrocytes tended to be higher in coculture with SVF, but this did not reach significance. This is likely explained by considerable inter-donor variation. However, we observed another interesting phenomenon: more cell death was found in $\mathrm{SVF}+\mathrm{CH}$ than in $\mathrm{ASC}+\mathrm{CH}$ coculture pellets.

This could possibly explain why on an average GAG production of each cell (GAG/DNA) is higher in $\mathrm{SVF}+\mathrm{CH}$ than in ASC+CH. Increased cell death of SVF, possibly in 
Table 1. Differentially Expressed Secreted Factors with More Than 2 Folds Change

\begin{tabular}{|c|c|c|}
\hline Symbol & Accession & $\begin{array}{l}\text { Fold change } \\
(A S C \text { vs SVF }\end{array}$ \\
\hline APOD & NM_001647.2 & -6.43455 \\
\hline PLA2G7 & NM_005084.2 & -5.71599 \\
\hline EFNB2 & NM_004093.2 & -4.92421 \\
\hline CXCL5 & NM_002994.3 & -4.32704 \\
\hline FABP4 & NM_001442.1 & -3.32248 \\
\hline LTB & NM_002341.1 & -2.79883 \\
\hline CFD & NM_001928.2 & -2.55915 \\
\hline THBD & NM_000361.2 & -2.55425 \\
\hline IL32 & NM_001012636.1 & -2.48646 \\
\hline LITAF & NM_004862.2 & -2.37264 \\
\hline FABP3 & NM_004102.3 & -2.2869 \\
\hline NID1 & NM_002508.2 & -2.19089 \\
\hline APOC1 & NM_001645.3 & -2.15423 \\
\hline LTA & NM_000595.2 & -2.14469 \\
\hline ATF3 & NM_001040619.1 & -2.13038 \\
\hline IGFBP7 & NM_001553.1 & 2.019207 \\
\hline BGN & NM_001711.3 & 2.20144 \\
\hline IGFBP6 & NM_002178.2 & 2.260575 \\
\hline FSTL1 & NM_007085.3 & 2.318603 \\
\hline ADAM19 & NM_033274.2 & 2.343654 \\
\hline FBLN1 & NM_006487.2 & 2.418595 \\
\hline F3 & NM_001993.2 & 2.446623 \\
\hline COL11A1 & NM_080629.2 & 2.50218 \\
\hline SERPINF1 & NM_002615.4 & 2.655044 \\
\hline FBLN2 & NM_001998.2 & 2.798432 \\
\hline EFEMP2 & NM_016938.2 & 2.833782 \\
\hline LOXL3 & NM_032603.2 & 3.072924 \\
\hline FN1 & NM_212474.1 & 3.253216 \\
\hline SFRP2 & NM_003013.2 & 3.32327 \\
\hline COL5A2 & NM_000393.3 & 3.63136 \\
\hline COL1A2 & NM_000089.3 & 3.631591 \\
\hline COL1A1 & NM_000088.3 & 4.273946 \\
\hline TGFBI & NM_000358.1 & 4.396439 \\
\hline POSTN & NM_006475.1 & 5.025622 \\
\hline DKK3 & NM_013253.4 & 5.166207 \\
\hline COL5A1 & NM_000093.3 & 5.221677 \\
\hline SPARC & NM_003118.2 & 5.568203 \\
\hline GREM1 & NM_013372.5 & 5.671927 \\
\hline MFGE8 & NM_005928.1 & 5.955669 \\
\hline
\end{tabular}

combination with increased proliferation of chondrocytes, is likely responsible for the relative overgrowth of chondrocytes after 4 weeks of coculture. This is particularly evident in the SVF coculture group compared to the ASC coculture group and was confirmed by STR analysis demonstrating that the initial seeding ratio of $\mathrm{CH}$ : SVF/ASC changed from 1:4 to 3:2 in case of coculture with SVF and $1: 3$ in case of ASC. We cannot rule out the possibility that some chondrocytes also died in coculture pellets. However, STR analysis in combination with the positive TUNEL staining suggests that predominantly the SVF, and to a lesser extent ASC, had disappeared from the cocultures by cell death.

Based on our results, SVF cells could be a very good, relatively easily accessible, and abundant source of cells to be used for cartilage regeneration. In previous studies, Jurgens et al. reported that SVF cells showed stem cell characteristics that are very similar to expanded cells isolated from SVF, and SVF cells even appeared to be slightly better than expanded cells isolated from SVF in chondrogenic differentiation as indicated by GAG quantification. ${ }^{15}$ In comparison with bone marrow-derived MSCs, SVF cells also differentiate into osteogenic, adipogenic, and chondrogenic lineages, but have a much higher colony-forming unit (CFU) frequency. ${ }^{42}$ It has also been reported that SVF cells could quickly attach to poly (L-lactide-co-caprolactone) and collagen type 1/3 scaffolds, both of which are suitable for cartilage tissue engineering. ${ }^{43}$

In this study, we show data to support that cocultured pellets of SVF cells and chondrocytes deposit more cartilage matrix than cocultured pellets of ASC and chondrocytes as well as monoculture of chondrocytes. Even after coimplantation of SVF or ASC in an alginate gel, more ectopic cartilage matrix formation is observed in the combination of SVF with chondrocytes after subcutaneous implantation in a nude mouse model. Improved cartilage formation in combination of SVF with $\mathrm{CH}$ was most clearly seen in the increased GAG deposition both in vitro and in vivo. It was less clear based on collagen type 2 deposition, in which the $\mathrm{CH}$ group displayed the strongest staining. This suggests that GAG and collagen type 2 deposition were independently regulated by coculture of $\mathrm{CH}$ with SVF.

Nevertheless, the superiority of the SVF chondrocyte combination over chondrocytes alone is still obvious for a practical reason, particularly if we take into consideration that the number of chondrocytes needed for coimplantation (SVF and chondrocytes) is much lower than that needed for a single implantation (chondrocytes alone). Since SVF can be relatively easy and quickly isolated out of a liposuction, it is possible to isolate SVF and reimplant the cells into the patient in a one-step surgery. ${ }^{44,45}$

In marked contrast to ASC, SVF contains a heterogeneous cell population. ${ }^{46}$ It is believed that ASC have a more homogeneous composition of cell types, even though ASC and SVF share some common features like multilineage differentiation. In addition to this, our data from FACs and microarray indicated that ASC resemble more mesenchymal cell lineages than SVF. This is in agreement with literature indicating that the SVF contains endothelial cell and hematopoietic cell populations besides a MSC fraction. ${ }^{42}$ With unknown mechanism, these nonmesenchymal cells enhanced the trophic effects of MSCs at least in coculture with chondrocytes.

There could be two hypotheses to explain this mechanism: (1) one or more of the non-MSC populations are actually better trophic mediators enhancing matrix formation of chondrocytes than MSCs; (2) some of the non-MSCs preserve/increase the trophic effects of MSCs. So far, we do not have enough data to exclude one of the above possibilities. However, pre-existing data seem to support the second. It has been reported that ASC resided in the adventitia of blood vessels as a group of $\mathrm{CD} 34^{+} / \mathrm{CD} 31^{-} / \alpha-$ smooth muscle actin- (smA) cells. ${ }^{47-49}$ Our previous data also demonstrated that a small fraction of CD146-positive cells were present in both SVF and ASC. ${ }^{14,15}$

There are debates about the CD markers of these cells $^{50,51}$; nevertheless, all these studies pointed out that ASC reside in a perivascular niche in situ. This niche or local microenvironment dominantly made of endothelial cells is important in maintaining the ASC phenotype as a 
A
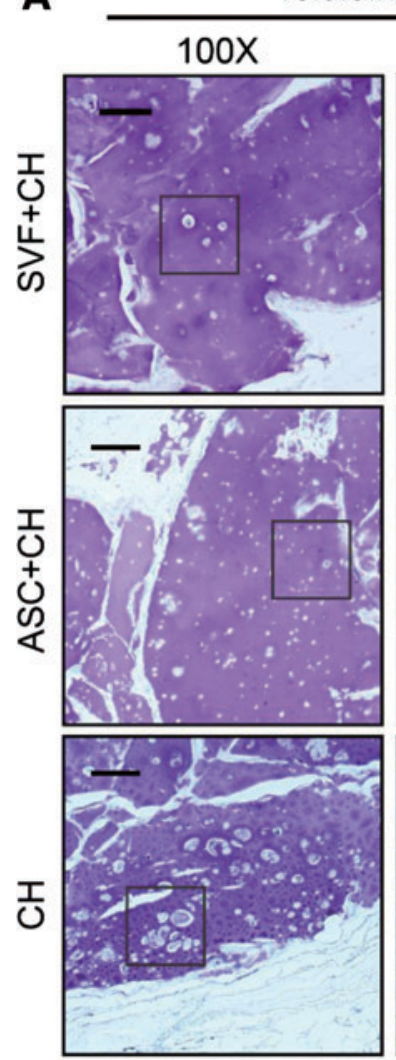

Toluidine Blue
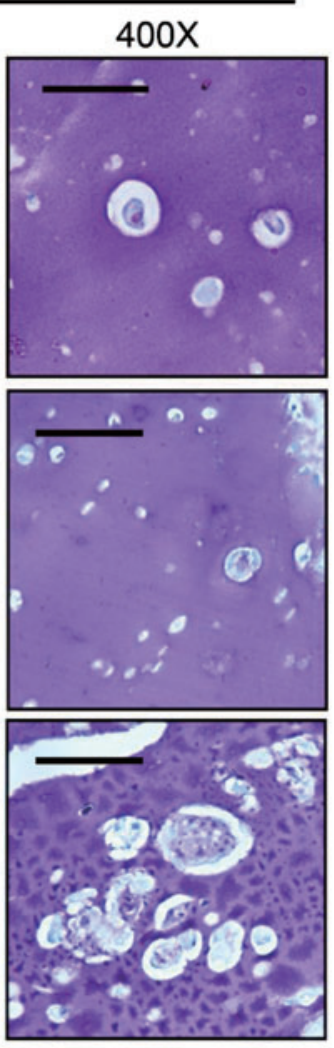

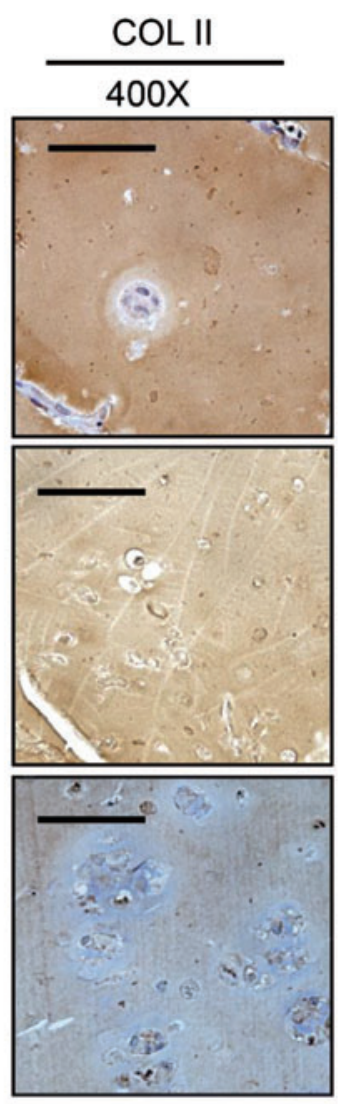

B
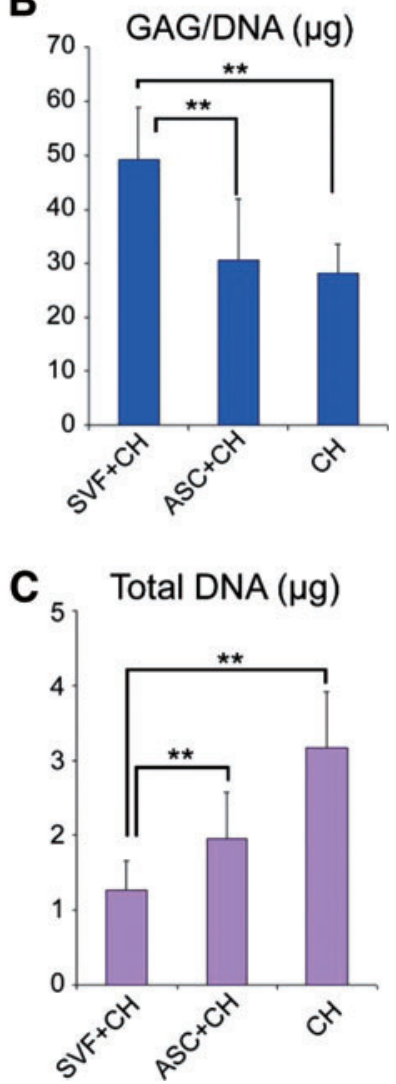

FIG. 5. Coimplantation of chondrocytes with SVF produces more GAG than with ASC. (A) SVF or ASC from three donors was pooled to eliminate donor variations, as well as chondrocytes from three donors. Then SVF or ASC were coimplanted with chondrocytes at a ratio of 4:1 into nude mice for 8 weeks. Constructs with chondrocyte only were served as positive control, while constructs without cells (blank) were used as negative control. Toluidine blue staining indicates the presence of GAGs. Immunohistochemical staining shows the expression of collagen type II. Scale $\mathrm{Bar}=100 \mu \mathrm{m}$. Right panel shows the enlarged images of the inserts in left panel. (B) GAG normalized to DNA in constructs. Amount of GAG and DNA of constructs $(N=8)$ were measured by GAG and DNA assay. Values were subtracted by blank constructs to eliminate the influence of material on GAG assay. Double asterisks represent $p<0.01$. NS = Not Significant. Error bar reflects SD. (C) Total DNA in TE constructs. Values were subtracted by blank constructs (without any cells) to eliminate the influence of material on GAG assay. Asterisk represents $p<0.05$. Double asterisks represent $p<0.01$. NS $=$ Not Significant. Error bar reflects SD. Color images available online at www .liebertpub.com/tea

stem cell. Although speculative, it may also be crucial for keeping the adipose stem cell's function as a trophic mediator. It was believed that ASC could stabilize endothelial networks in vitro and help vessel formation in vivo. ${ }^{52}$ As a feedback, it is also possible that endothelial cells may better preserve some of the adipose stem cell's characteristics which are lost during in vitro expansion, such as their ability to express trophic mediators.

Regarding the interaction between different cell populations in SVF, one possible interaction that we should keep in mind is the one between hematopoietic cells and MSCs. It was reported that MSCs could support hematopoiesis in culture. ${ }^{53}$ In turn, hematopoietic cells such as monocytes and lymphocytes, which are abundant in SVF but absent after in vitro expansion, may also regulate the trophic property of MSCs.

In conclusion, our data demonstrated that chondrocytes form better cartilage tissue when cocultured or coimplanted with SVF of adipose tissue than with ASC. Heterogeneous populations of SVF show higher level of trophic effects in cartilage formation. These results support the clinical potential of a one-step therapy for cartilage repair, in which SVF from adipose tissue and chondrocytes from the nonweight bearing joint surface are isolated, mixed, and implanted back into the patient during the same surgical procedure.

\section{Acknowledgments}

The authors acknowledge the support of the translational excellence in regenerative medicine Smart Mix Program of the Netherlands Ministry of Economic Affairs and the Netherlands Ministry of Education, Culture, and Science. M.K. is supported by a long-term program subsidy of the Dutch Arthritis Association.

\section{Disclosure Statement}

No competing financial interests exist. 


\section{References}

1. Dell'accio, F., and Vincent, T.L. Joint surface defects: clinical course and cellular response in spontaneous and experimental lesions. Eur Cell Mater 20, 210, 2010.

2. Sledge, S.L. Microfracture techniques in the treatment of osteochondral injuries. Clin Sports Med 20, 365, 2001.

3. Brittberg, M., Lindahl, A., Nilsson, A., Ohlsson, C., Isaksson, O., and Peterson, L. Treatment of deep cartilage defects in the knee with autologous chondrocyte transplantation. N Engl J Med 331, 889, 1994.

4. Alford, J.W., and Cole, B.J. Cartilage restoration, part 2: techniques, outcomes, and future directions. Am J Sports Med 33, 443, 2005.

5. Robert, H. Chondral repair of the knee joint using mosaicplasty. Orthop Traumatol Surg Res 97, 418, 2011.

6. Niemeyer, P., Pestka, J.M., Kreuz, P.C., Erggelet, C., Schmal, H., Suedkamp, N.P., and Steinwachs, M. Characteristic complications after autologous chondrocyte implantation for cartilage defects of the knee joint. Am J Sports Med 36, 2091, 2008.

7. Vadala, G., Studer, R.K., Sowa, G., Spiezia, F., Iucu, C., Denaro, V., Gilbertson, L.G., and Kang, J.D. Coculture of bone marrow mesenchymal stem cells and nucleus pulposus cells modulate gene expression profile without cell fusion. Spine (Phila Pa 1976) 33, 870, 2008.

8. Mo, X.T., Guo, S.C., Xie, H.Q., Deng, L., Zhi, W., Xiang, Z., Li, X.Q., and Yang, Z.M. Variations in the ratios of cocultured mesenchymal stem cells and chondrocytes regulate the expression of cartilaginous and osseous phenotype in alginate constructs. Bone 45, 42, 2009.

9. Tsuchiya, K., Chen, G., Ushida, T., Matsuno, T., and Tateishi, T. The effect of coculture of chondrocytes with mesenchymal stem cells on their cartilaginous phenotype in vitro. Mater Sci Eng C-Biomimetic Supramol Syst 24, 6, 2004.

10. Leijten, J.C., Georgi, N., Wu, L., van Blitterswijk, C.A., and Karperien, M. Cell sources for articular cartilage repair strategies: shifting from monocultures to cocultures. Tissue Eng Part B Rev 19, 31, 2013.

11. Zuk, P.A., Zhu, M., Mizuno, H., Huang, J., Futrell, J.W., Katz, A.J., Benhaim, P., Lorenz, H.P., and Hedrick, M.H. Multilineage cells from human adipose tissue: implications for cell-based therapies. Tissue Eng 7, 211, 2001.

12. Zuk, P.A., Zhu, M., Ashjian, P., De Ugarte, D.A., Huang, J.I., Mizuno, H., Alfonso, Z.C., Fraser, J.K., Benhaim, P., and Hedrick, M.H. Human adipose tissue is a source of multipotent stem cells. Mol Biol Cell 13, 4279, 2002.

13. Lin, Y., Liu, L., Li, Z., Qiao, J., Wu, L., Tang, W., Zheng, X., Chen, X., Yan, Z., and Tian, W. Pluripotency potential of human adipose-derived stem cells marked with exogenous green fluorescent protein. Mol Cell Biochem 291, 1, 2006.

14. Varma, M.J., Breuls, R.G., Schouten, T.E., Jurgens, W.J., Bontkes, H.J., Schuurhuis, G.J., van Ham, S.M., and van Milligen, F.J. Phenotypical and functional characterization of freshly isolated adipose tissue-derived stem cells. Stem Cells Dev 16, 91, 2007.

15. Jurgens, W.J., van Dijk, A., Doulabi, B.Z., Niessen, F.B., Ritt, M.J., van Milligen, F.J., and Helder, M.N. Freshly isolated stromal cells from the infrapatellar fat pad are suitable for a one-step surgical procedure to regenerate cartilage tissue. Cytotherapy 11, 1052, 2009.
16. Wu, L., Leijten, J.C., Georgi, N., Post, J.N., van Blitterswijk, C.A., and Karperien, M. Trophic effects of mesenchymal stem cells increase chondrocyte proliferation and matrix formation. Tissue Eng Part A 17, 1425, 2011.

17. Acharya, C., Adesida, A., Zajac, P., Mumme, M., Riesle, J., Martin, I., and Barbero, A. Enhanced chondrocyte proliferation and mesenchymal stromal cells chondrogenesis in coculture pellets mediate improved cartilage formation. J Cell Physiol 227, 88, 2012.

18. Wu, L., Prins, H.J., Helder, M., van Blitterswijk, C., and Karperien, M. Trophic effects of mesenchymal stem cells in chondrocyte co-cultures are independent of culture conditions and cell sources. Tissue Eng Part A 18, 1542, 2012.

19. Singer, M. Trophic functions of the neuron. VI. Other trophic systems. Neurotrophic control of limb regeneration in the newt. Ann N Y Acad Sci 228, 308, 1974.

20. Caplan, A.I., and Dennis, J.E. Mesenchymal stem cells as trophic mediators. J Cell Biochem 98, 1076, 2006.

21. Bruder, S.P., Fink, D.J., and Caplan, A.I. Mesenchymal stem cells in bone development, bone repair, and skeletal regeneration therapy. J Cell Biochem 56, 283, 1994.

22. Kassis, I., Vaknin-Dembinsky, A., and Karussis, D. Bone marrow mesenchymal stem cells: agents of immunomodulation and neuroprotection. Curr Stem Cell Res Ther 6, 63, 2011.

23. Li, Y., Chen, J., Zhang, C.L., Wang, L., Lu, D., Katakowski, M., Gao, Q., Shen, L.H., Zhang, J., Lu, M., and Chopp, M. Gliosis and brain remodeling after treatment of stroke in rats with marrow stromal cells. Glia 49, 407, 2005.

24. Sassoli, C., Pini, A., Mazzanti, B., Quercioli, F., Nistri, S., Saccardi, R., Orlandini, S.Z., Bani, D., and Formigli, L. Mesenchymal stromal cells affect cardiomyocyte growth through juxtacrine Notch-1/Jagged1 signaling and paracrine mechanisms: clues for cardiac regeneration. J Mol Cell Cardiol 51, 399, 2011.

25. Tang, Y.L., Zhao, Q., Qin, X., Shen, L., Cheng, L., Ge, J., and Phillips, M.I. Paracrine action enhances the effects of autologous mesenchymal stem cell transplantation on vascular regeneration in rat model of myocardial infarction. Ann Thorac Surg 80, 229, 2005.

26. Hendriks, J., Riesle, J., and Vanblitterswijk, C.A. Effect of stratified culture compared to confluent culture in monolayer on proliferation and differentiation of human articular chondrocytes. Tissue Eng 12, 2397, 2006.

27. Jurgens, W.J., Oedayrajsingh-Varma, M.J., Helder, M.N., Zandiehdoulabi, B., Schouten, T.E., Kuik, D.J., Ritt, M.J., and van Milligen, F.J. Effect of tissue-harvesting site on yield of stem cells derived from adipose tissue: implications for cell-based therapies. Cell Tissue Res 332, 415, 2008.

28. Lee, S.Y., Nakagawa, T., and Reddi, A.H. Mesenchymal progenitor cells derived from synovium and infrapatellar fat pad as a source for superficial zone cartilage tissue engineering: analysis of superficial zone protein/lubricin expression. Tissue Eng Part A 16, 317, 2010.

29. Livak, K.J., and Schmittgen, T.D. Analysis of relative gene expression data using real-time quantitative PCR and the 2(-Delta Delta C(T)) Method. Methods 25, 402, 2001.

30. $\mathrm{Hu}, \mathrm{J}$., and $\mathrm{He}, \mathrm{X}$. Enhanced quantile normalization of microarray data to reduce loss of information in gene expression profiles. Biometrics 63, 50, 2007.

31. Szklarczyk, D., Franceschini, A., Kuhn, M., Simonovic, M., Roth, A., Minguez, P., Doerks, T., Stark, M., Muller, J., 
Bork, P., Jensen, L.J., and von Mering, C. The STRING database in 2011: functional interaction networks of proteins, globally integrated and scored. Nucleic Acids Res 39, D561, 2011.

32. Cline, M.S., Smoot, M., Cerami, E., Kuchinsky, A., Landys, N., Workman, C., Christmas, R., Avila-Campilo, I., Creech, M., Gross, B., Hanspers, K., Isserlin, R., Kelley, R., Killcoyne, S., Lotia, S., Maere, S., Morris, J., Ono, K., Pavlovic, V., Pico, A.R., Vailaya, A., Wang, P.L., Adler, A., Conklin, B.R., Hood, L., Kuiper, M., Sander, C., Schmulevich, I., Schwikowski, B., Warner, G.J., Ideker, T., and Bader, G.D. Integration of biological networks and gene expression data using Cytoscape. Nat Protoc 2, 2366, 2007.

33. Abramoff, M., Magelhaes, P., and Ram, S. Image Processing with ImageJ. Biophotonics Int 11, 8, 2004.

34. Maumus, M., Peyrafitte, J.A., D’Angelo, R., Fournier-Wirth, C., Bouloumie, A., Casteilla, L., Sengenes, C., and Bourin, P. Native human adipose stromal cells: localization, morphology and phenotype. Int J Obes 35, 1141, 2011.

35. Corselli, M., Chen, C.W., Sun, B., Yap, S., Rubin, J.P., and Peault, B. The tunica adventitia of human arteries and veins as a source of mesenchymal stem cells. Stem Cells Dev 21, 1299, 2012.

36. Huang, A.H., Stein, A., and Mauck, R.L. Evaluation of the complex transcriptional topography of mesenchymal stem cell chondrogenesis for cartilage tissue engineering. Tissue Eng Part A 16, 2699, 2010.

37. Leijten, J.C., van Blitterwijk, C.A., Karperien, M., Emons, J., van Gool, S., Wit, J.M., Sticht, C., Decker, E., Rappold, G., Uitterlinden, A., Rivadeneira, F., van Meurs, J., Hofman, A., and Scherjon, S. GREM1, FRZB and DKK1 are key regulators of human articular cartilage homeostasis. Arthritis Rheum 64, 3302, 2012.

38. Morello, R., Bertin, T.K., Schlaubitz, S., Shaw, C.A., Kakuru, S., Munivez, E., Hermanns, P., Chen, Y., Zabel, B., and Lee, B. Brachy-syndactyly caused by loss of Sfrp2 function. J Cell Physiol 217, 127, 2008.

39. Kapinas, K., Lowther, K.M., Kessler, C.B., Tilbury, K., Lieberman, J.R., Tirnauer, J.S., Campagnola, P., and Delany, A.M. Bone matrix osteonectin limits prostate cancer cell growth and survival. Matrix Biol 31, 299, 2012.

40. Xiao, S.M., Gao, Y., Cheung, C.L., Bow, C.H., Lau, K.S., Sham, P.C., Tan, K.C., and Kung, A.W. Association of CDX1 binding site of periostin gene with bone mineral density and vertebral fracture risk. Osteoporos Int 23, 1877, 2012.

41. Lin, Y., Luo, E., Chen, X., Liu, L., Qiao, J., Yan, Z., Li, Z., Tang, W., Zheng, X., and Tian, W. Molecular and cellular characterization during chondrogenic differentiation of adipose tissue-derived stromal cells in vitro and cartilage formation in vivo. J Cell Mol Med 9, 929, 2005.

42. Astori, G., Vignati, F., Bardelli, S., Tubio, M., Gola, M., Albertini, V., Bambi, F., Scali, G., Castelli, D., Rasini, V., Soldati, G., and Moccetti, T. "In vitro" and multicolor phenotypic characterization of cell subpopulations identified in fresh human adipose tissue stromal vascular fraction and in the derived mesenchymal stem cells. J Transl Med 5, 55, 2007.

43. Jurgens, W.J., Kroeze, R.J., Bank, R.A., Ritt, M.J., and Helder, M.N. Rapid attachment of adipose stromal cells on resorbable polymeric scaffolds facilitates the one-step surgical procedure for cartilage and bone tissue engineering purposes. J Orthop Res 29, 853, 2011.
44. Helder, M.N., Knippenberg, M., Klein-Nulend, J., and Wuisman, P.I. Stem cells from adipose tissue allow challenging new concepts for regenerative medicine. Tissue Eng 13, 1799, 2007.

45. Farre-Guasch, E., Marti-Page, C., Hernadez-Alfaro, F., Klein-Nulend, J., and Casals, N. Buccal fat pad, an oral access source of human adipose stem cells with potential for osteochondral tissue engineering: an in vitro study. Tissue Eng Part C Methods 16, 1083, 2010.

46. Gimble, J.M., Grayson, W., Guilak, F., Lopez, M.J., and Vunjak-Novakovic, G. Adipose tissue as a stem cell source for musculoskeletal regeneration. Front Biosci (Schol Ed) 3, 69, 2011.

47. Lin, C.S., Xin, Z.C., Deng, C.H., Ning, H., Lin, G., and Lue, T.F. Defining adipose tissue-derived stem cells in tissue and in culture. Histol Histopathol 25, 807, 2010.

48. Zimmerlin, L., Donnenberg, V.S., Pfeifer, M.E., Meyer, E.M., Peault, B., Rubin, J.P., and Donnenberg, A.D. Stromal vascular progenitors in adult human adipose tissue. Cytometry A 77, 22, 2010.

49. Crisan, M., Yap, S., Casteilla, L., Chen, C.W., Corselli, M., Park, T.S., Andriolo, G., Sun, B., Zheng, B., Zhang, L., Norotte, C., Teng, P.N., Traas, J., Schugar, R., Deasy, B.M., Badylak, S., Buhring, H.J., Giacobino, J.P., Lazzari, L., Huard, J., and Peault, B. A perivascular origin for mesenchymal stem cells in multiple human organs. Cell Stem Cell 3, 301, 2008.

50. Zannettino, A.C., Paton, S., Arthur, A., Khor, F., Itescu, S., Gimble, J.M., and Gronthos, S. Multipotential human adipose-derived stromal stem cells exhibit a perivascular phenotype in vitro and in vivo. J Cell Physiol 214, 413, 2008.

51. Cai, X., Lin, Y., Hauschka, P.V., and Grottkau, B.E. Adipose stem cells originate from perivascular cells. Biol Cell 103, 435, 2011.

52. Traktuev, D.O., Prater, D.N., Merfeld-Clauss, S., Sanjeevaiah, A.R., Saadatzadeh, M.R., Murphy, M., Johnstone, B.H., Ingram, D.A., and March, K.L. Robust functional vascular network formation in vivo by cooperation of adipose progenitor and endothelial cells. Circ Res 104, 1410, 2009.

53. Corselli, M., Chin, C.J., Parekh, C., Sahaghian, A., Wang, W., Ge, S., Evseenko, D., Wang, X., Montelatici, E., Lazzari, L., Crooks, G.M., and Peault, B. Perivascular support of human hematopoietic stem/progenitor cells. Blood 121, 2891, 2013.

Address correspondence to: Marcel Karperien, PhD

Department of Developmental BioEngineering MIRA Institute for Biomedical Technology and Technical Medicine University of Twente P.O. Box 217

Enschede 7500AE The Netherlands

E-mail: h.b.j.karperien@utwente.nl

Received: June 10, 2015

Accepted: December 9, 2015

Online Publication Date: February 1, 2016 